\title{
Determinants of Competitiveness of the Swaziland Sugar Industry
}

\author{
Knowledge Ndlangamandla \\ P.O. Box 14, Nhlangano, Swaziland. \\ Douglas Kibirige \\ Department of Agricultural Economics and Management, University of Swaziland, \\ Swaziland. \\ Jeremiah I. Rugambisa \\ Department of Agricultural Economics and Management, University of Swaziland, \\ Swaziland.
}

Received: August 3, 2016

Accepted: August 13, 2016

Published: August 22, 2016

doi:10.5296/jas.v4i3.9925

URL: http://dx.doi.org/10.5296/jas.v4i3.9925

\begin{abstract}
The issue of abolishment of trade agreements preferences pose a great threat to the sugar industry in Swaziland. Using both the Relative Trade Advantage and Porter's 1990 National Diamond concept, the major objective of the study was to examine the comparative advantage of the sugar industry in the global market with the aim of establishing the contributing factors and constraints to the competitiveness of the Swaziland sugar industry. The Relative Trade Advantage (RTA) method developed by Balassa was used to determine Swaziland global comparative advantage of the sugar industry. The study found that the Swaziland sugar industry had a relatively highly comparative advantage in the global market in terms of producing sugar. The results from the regression model indicated that global sugar market prices, exchange rate and export values had a significant influence on the Swaziland Relative Trade Advantage indices. The Porter`s (1990) National Diamond model analysis revealed factors that enhance competitiveness of the sugar industry include compensation of management, business approach to human resource, relationship and networking, telecommunication and internet service, availability of credit and availability of unskilled labour as well as production of high quality products. Some factors that have a major constraining effect on the competitiveness were the small local market size, cost of financing business, cost of transport, cost of supply of inputs, public sector effectiveness on service delivery and exchange rates. Therefore, the government in consultation with the industry representatives should consider development and implementation of an industry policy
\end{abstract}


strategy for the sugar industry intended to ensure its survival. Other strategies would be to improve efficiencies at both field and factory levels as well as diversification or value addition on the product.

Keywords: Trade liberalisation, Revealed Comparative Advantage, RTA and Competitiveness

\section{Introduction}

The Swaziland sugar industry has been a success story. The success of the industry and the basis for further expansion can be attributed to the preferential markets that have been provided by developed countries particularly in Europe and the USA (Swaziland Sugar Association report, 2013). While there have been significant improvements in sugar production in the recent past, there remains significant factors that affect the external environment in which the Swaziland sugar industry operates. Swaziland sugar industry suffers from the decline by $36 \%$ in the preference price of raw sugar sold on the EU market (SSA, 2012).

In addition to the decline of the sugar prices in the European Union (EU) market, Swazi sugar industry continues to suffer from global trade liberalization and complete abolishment of preferential markets access in the European Union and United States of America markets (Gass, 2012). Globalisation and abolishment of trade agreement would have serious impact on the country`s economy, incomes and employment (Matsebula, 2008). Another challenge facing the sugar industry in Swaziland according to Gass (2012) is to ensure its growth ability on a sustainable basis.

According to the researcher's knowledge, there is limited information related to the competitiveness and factors that could contribute to the competitiveness of the Swaziland sugar industry. Therefore, this study aims at estimating competitiveness of the sugar industry and determinants of its competitiveness.

Using both the Relative Trade Advantage and Porter`s 1990 National Diamond concept, the major objective of the study was to examine the competitiveness of the Swaziland sugar industry in the global market with the aim of establishing the contributing factors to the competitiveness of the sugar industry. This was achieved through the following specific objectives:

1. To determine Swaziland`s comparative advantage in global sugar trade.

2. To estimate factors affecting the Relative Trade Advantage of Swaziland sugar industry.

3. To identify the determinants of the competitiveness of the sugar industry in Swaziland. 


\section{Theoretical framework}

\subsection{Conceptual perspectives of competitiveness}

The literature investigating competitiveness, whether at the country, region, sector or enterprise level, proposes many different measures for evaluating it (Esterhuizen, 2006). Trade indicators include Real Exchange Rate (RER), Revealed Comparative Advantage (RCA) and economic performance indicators like costs of production, profitability, productivity and efficiency as well as the Strength, Weakness, Opportunities and Threat (SWOT) as stated by Valentin (2001).

Revealed comparative advantage (RCA) which is sometimes called Ballasa index was first formulated by Balassa (1965) and modified by Vollrath (1991) to the Relative Trade Advantage in order to come up with the RTA indices. The RTA indicator implicitly weighs the revealed comparative advantage.

The concept of "Revealed Comparative Advantage" by Ballassa is widely used in practice to determine a country's weak and strong sectors. For a particular country, the revealed comparative advantage in a product is defined as the ratio of the share of that product in world trade. If this index takes a value greater than unity, the country is considered to have a revealed comparative advantage in the product while a value below unity indicates a comparative disadvantage. Vollrath's (1991) modified version of the Revealed Comparative Advantage is called the relative export advantage (RXA) measure, as it is based on exports. It measures normalised export shares, where the normalisation is with respect to the exports of the same industry in the group of reference countries. This method can identify sectors or commodities for which an individual country has a comparative advantage or disadvantage.

\subsection{Determinants of Competitiveness}

Porter (1990) was one of the first to underline the importance of firm's strategy and structure in developing their competitiveness. Porter (1990) identified four classes of country attributes (which he calls the National Diamond) that provide the underlying conditions or platform for the determination of the national competitive advantage. These are factor conditions, demand conditions, related and support industries, and company strategy, structure and rivalry. He also proposes two other factors, namely government policy and chance (exogenous shocks), that support and complement the system of national competitiveness but do not create lasting competitive advantages

Factor conditions - This is the nation`s position in factors of production. Factor conditions are further subdivided into basic and advanced factors that can be either general or specialised.

the nation's position in factors of production such as skilled labour, quality of production factors, natural resources, fuel, machinery and infrastructure, necessary to compete in a given industry. 


\section{Ml Macrothink}

Demand conditions - This is the nation's home demand for the industry`s products. According to Porter (1990), it is not only the size of the home demand that matters, but also the sophistication of home country buyers. It is the composition of home demand that shapes how firms perceive, interpret and respond to buyers' needs. These include nature of the local customers, internalization of the customers, concerns on ethics, the size and growth of the domestic market.

Related and Supporting Firms - The presence or absence in the nation of supplier industries and related industries that are international competitive. These are industries that can use and coordinate particular activities in the value chain together, or that are concerned with complementary products. These include availability and access to credit facilities, scientific research institutions, telecommunication and electricity.

Firm Strategy, Structure and Rivalry Conditions - This characteristic ascribes to the national - level circumstances that differentiate the creation, organisation and the management of firms and the nature of national level competition. Intense and positive rivalry between firms in a country shape firms for global competition and assists to constraint and establish a business climate attractive for foreign and domestic investment. These include investment in research and development, the source of competition in the local market and approaches in human resource.

Government - The role of government is seen by Porter (1998) as influencing the four attributes above. This includes the effect of the tax system, trade policies, and administration regulations.

Chance Condition - Porter (1990) also added another outside variable to the competitive diamond model called chance conditions. Chance conditions may be defined as events described as occurrences that have less to do with circumstances in a nation and that are mainly beyond the influence and power of firms and local government. These include the significance of crime, HIV and AIDS in the country, the impact of the exchange rate and the political environment.

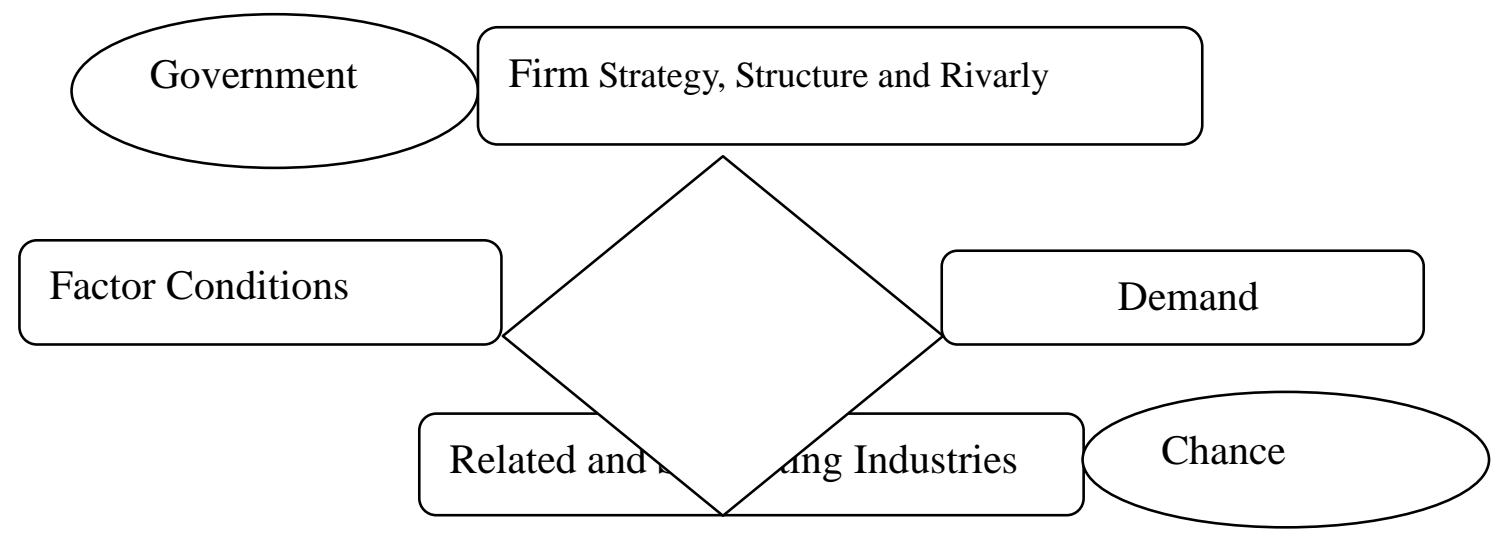

Figure 1. Porter`s Diamond Model

Source: Porter, 1990. 


\section{$\Lambda$ Macrothink}

\section{Methodology}

\subsection{Research Design}

This quantitative study was undertaken to determine the competitiveness of the Swaziland sugar industry. Analysing a firm competitiveness require that the underlying factors that influence the competitiveness of individual firms and industries be examined (Porter, 1998). Therefore, a descriptive study using Porter's (1998) theory to determine the factors affecting the competitiveness of the sugar industry of Swaziland was undertaken.

\subsection{Sampling and Data Collection}

To measure how competitive the Sugar industry in Swaziland is, it was necessary to determine how successful the sector traded its products relative to its competitors, over time in the international market. For this purpose export data was needed to compare the Swaziland Sugar industry performance against global competition. Therefore, data on export values for sugar between 1994 to 2011 was obtained from FAOSTAT and SSA for the purpose of determining the competitiveness of the sugar industry. Also export values of sugar and that of all agricultural products for South Africa, Brazil and Australia were obtained using the same data source.

Also for the determinants of competitiveness of the sugar industry primary data was obtained through a perception survey of key stakeholders regarding the competitiveness of the Swaziland sugar industry where purposive sample of 30 key sugar industry stakeholders was selected. A structured self-administered questionnaire which was developed using Porter's (1990) determinants to competitiveness as a basis was administered.

\subsection{Data Analysis}

\subsubsection{Estimating the Revealed Comparative Advantage of Swaziland Sugar Industry}

Microsoft Excel Spreadsheet was used to capture, present and analyse export values for the sugar not only that from Swaziland but also those from its competitors in the global sugar market.The analysis in this research was based on the Relative Trade Advantage model developed in economic theory by Balassa (1977). This model allowed the analysis of the comparative advantage status of the Swaziland sugar industry. The RTA indices were based on the export values of sugar since Swaziland is a major exporter of sugar. Therefore, the RTA indices were calculated as follows.

$\mathrm{RTA}=\mathrm{RXA}$

$\mathrm{RXA}=[\mathrm{Xiv} / \Sigma \mathrm{Xin}] /[\Sigma \mathrm{Xmv} / \Sigma \mathrm{Xmn}]$

Where;

$(\mathrm{i}$ and $\mathrm{m})=$ Products

$\mathrm{i}$ = Sugar export 
$\mathrm{m}=$ other agricultural export products except sugar.

$(\mathrm{v}$ and $\mathrm{n})=$ countries

$\mathrm{v}=$ Swaziland

$\mathrm{n}=$ other countries

$\mathrm{Xiv}=$ Value of Swaziland exports for sugar $(\mathrm{MT})$

$\Sigma$ Xin $=$ Total value of exports for sugar from all countries except Swaziland (MT)

$\Sigma \mathrm{Xmv}=$ Total value of Swaziland agricultural exports, except for sugar (MT).

$\Sigma$ Xmn $=$ Total Value of global agricultural exports of all other products (MT).

RTA $>1$ implies that the industry has a comparative advantage

RTA $<1$ implies that the industry has a comparative disadvantage

$\mathrm{RTA}=1$ is said to be marginally competitive

\subsubsection{Estimating Determinants of Swaziland sugar industry's Relative Trade Advantage}

To estimate the factors affecting the Relative Trade Advantage of Swaziland sugar industry, a regression analysis was used to estimate the relationship between the independent factors $(\mathrm{Xi})$ and Relative Trade Advantage (RTA) indices which is the dependent variable. Among these factors were land cultivated, yields, the global sugar prices, exchange rates, value of Swaziland exports for sugar, total value of exports for sugar from all countries except Swaziland, total value of Swaziland agricultural exports, except for sugar, total value of global agricultural exports of all other products. The factors were analysed using SPSS Version 20. The least-squares technique was used to estimate the multiple regression coefficients $(b i)$ in an equation form:

$$
\mathrm{RTA}=\beta_{0}+\beta_{1} \mathrm{X}_{1}+\beta_{2} \mathrm{X}_{2}+\beta_{3} \mathrm{X}_{3}+\beta_{4} \mathrm{X}_{4}+\beta_{5} \mathrm{X}_{5}+\beta_{6} \mathrm{X}_{6}+\beta_{7} \mathrm{X}_{7}+\beta_{8} \mathrm{X}_{8}+u
$$

Where;

RTA $=$ Relative Trade Advantage indices

$\beta_{0}=$ Constant

$\beta_{1} \ldots \beta_{8}=$ Parameters to be estimated

$\mathrm{X}_{1}=$ land cultivated (ha)

$\mathrm{X}_{2}=$ yield $(\mathrm{t} / \mathrm{ha})$

$\mathrm{X}_{3}=$ Global Price of sugar $(\mathrm{U} \$ /$ tonne $)$

$\mathrm{X}_{4}=$ Exchange rate (1US\$/ZAR)

$\mathrm{X}_{5}=$ Value of Swaziland exports for sugar (MT).

$\mathrm{X}_{6}=$ Total value of exports for sugar from all countries except Swaziland (MT) 
$\mathrm{X}_{7}=$ Total value of Swaziland exports, except for sugar (MT).

$\mathrm{X}_{8}=$ Total Value of global exports of all other products (MT)

$\mathrm{U}=$ Random disturbance term.

3.3.3 Estimating factors affecting Swaziland's sugar industry competitiveness

To identify the determinants of the competitiveness of the sugar industry in Swaziland, the approach to competitiveness developed by Porter $(1990 ; 1998)$ was used as base for the determinants of competitiveness of the sugar industry from the executive survey of 2015 of the population of stakeholders along the sugar industry. Sixty three factors were investigated and these factors were examined into six categories namely factor conditions, demand condition, related and supporting firm, firm strategy, structure and rivalry, government conditions and chance conditions.

The data obtained through the executive survey were analysed using the SPSS Version 20 to obtain their mean, median, standard deviation and mode of each of the sixty three factors investigated. In the study the determinants of competition were rated to have either constraints (1- 2.99), moderate (3 - 3.99) or enhancing (4 -5.99) impact on competitiveness of the sugar industry in Swaziland. The factors were ranked using their median values.

\section{Results of the Study}

\subsection{Comparative advantage of the Swaziland sugar industry}

From Table 1 it is reflected that out of the four countries, Swaziland's RTA indices reflect a highly comparative advantage status than the others with RTAs indices ranging from 2.8 and 46 except in 2008 when it was not competitive. The high RTA indices can be attributed to an increase in the value of exports of sugar from Swaziland compared to other agricultural exports in Swaziland. In 2003 South Africa had a highly comparative advantage with her RTA indices reaching 46.3. In 2004 Australia also had a highly comparative advantage with her RTA indices reaching 53.3. However, in 2011 Brazil`s RTA indice was 6.2 and reflected a relative high comparative advantage than the others. 
Table 1. Comparative Advantage of the sugar industry

\begin{tabular}{lllll}
\hline & & & & South \\
Year & Swaziland & Australia & Brazil & Africa \\
RTA & RTA & RTA & RTA \\
\hline 1994 & 13.7 & 0.5 & 5.3 & 6.0 \\
1995 & 6.6 & 4.7 & 1.1 & 0.5 \\
1996 & 14.6 & 1.6 & 7.4 & 3.1 \\
1997 & 22.0 & 1.1 & 3.7 & 2.8 \\
1998 & 9.30 & 0.6 & 3.9 & 1.1 \\
1999 & 21.1 & 2.2 & 5.1 & 4.1 \\
2000 & 46.0 & 1.2 & 7.2 & 5.3 \\
2001 & 34.9 & 14.3 & 2.9 & 1.3 \\
2002 & 16.5 & 1.2 & 4.3 & 3.5 \\
2003 & 38.5 & 30.2 & 16.3 & 46.3 \\
2004 & 26.7 & 53.3 & 35.4 & 18.1 \\
2005 & 6.1 & 1.9 & 1.8 & 2.9 \\
2006 & 8.5 & 1.3 & 1.6 & 4.8 \\
2007 & 14.0 & 0.03 & 2.3 & 0.8 \\
2008 & 0.8 & 0.4 & 3.6 & 0.1 \\
2009 & 28.0 & 9.8 & 0.6 & 1.7 \\
2010 & 34.5 & 0.9 & 10.6 & 1.2 \\
2011 & 2.8 & 0.9 & 6.2 & 0.5 \\
\hline
\end{tabular}

Source: Own calculation based on data from FAOSTAT 1994 - 2011

Note: Competitive (RTA $>1)$, not competitive $($ RTA $<1)$, marginal competitive $($ RTA = 1)

4.2 An analysis of the Factors that Influence the Sugar Industry`s Relative Trade Advantage Competitive

The factors which were analysed using SPSS includes land cultivated (ha), yield (t/ha), the global sugar prices (US\$), exchange rates, value of Swaziland exports for sugar (MT), total

value of exports for sugar from all countries except Swaziland (MT), total value of Swaziland agricultural exports except for sugar (MT), total value of global agricultural exports of all other products (MT).

Table 2 below show the results from the multiple regression model. About $70 \%$ variation in the RTAs is explained by these factors. The results indicate that only three factors signicantly affect the comparative advantage of the sugar industry and they are significant at $(\mathrm{P}<0.05)$, $(\mathrm{P}<0.05)$, $(\mathrm{P}<0.1)$, respectively, namely the global price for sugar, exchange rate and the value of Swaziland exports.

The coefficient of global sugar price was -0.148 . This means that an increase by one unit in the global price would result to 0.148 decrease in the comparative advantage of the sugar industry in Swaziland. This means that when the global price of sugar increases more sugar 
industries will come in to benefit from the high price thus creating more competition among the sugar industry exporters. The presence of more competitors in the international sugar market would result to the reduction of the comparative advantage of the sugar industry. The negative sign shows that Swaziland competitiveness advantage will be reduced at global market.

The other factor which had a positive significant $(\mathrm{P}<0.05)$ influence on the comparative advantage of the sugar industry was the exchange rate. The coefficient was 3.807. It shows that a unit increase in the exchange rate would increase the competitive advantage of the sugar industry by 3.807. In the case of Swaziland, profit margins of the sugar exporters are likely to increase due to increase in the value of exports. This will benefit greatly the sugar industry since it would be able to reinvest part of the revenues in technology to improve efficiency and also increase more land under cultivation with improved irrigation facilities.

The last factor which had a positive significant $(\mathrm{P}<0.1)$ influence on the sugar industries competitiveness was the value of export. A unit increase in the value of export would results to $2.74 \times 10^{-5}$ increase in the competitive advantage of the sugar industry. The more the sugar industry exports, the more it enhances its chances of being competitive in the global markets.

Table 2. Competitive Determinants of the Relative Trade Advantage

\begin{tabular}{lllll}
\hline Item & Coefficient & Std.Error & T- value & Sig. \\
\hline Intercept & 11.66 & 34.653 & 0.336 & 0.744 \\
Land cultivated (ha) & $-2.89 \mathrm{E}-05$ & 0.000 & -1.315 & 0.221 \\
Yield (tonne/ha) & 0.188 & 0.297 & 0.633 & 0.542 \\
Global sugar prices (U\$) & -0.148 & 0.05 & -2.944 & $0.016^{* *}$ \\
Exchange rate (U\$/ZAR) & 3.807 & 1.626 & 2.342 & $0.044^{* *}$ \\
Swaziland sugar export (MT) & $2.74 \mathrm{E}-05$ & 0.000 & 2.18 & $0.057^{*}$ \\
Global sugar export except Swaziland & & & & \\
(MT) & $-1.43 \mathrm{E}-07$ & 0.000 & -1.583 & 0.148 \\
Swaziland Export except sugar (MT) & $-4.08 \mathrm{E}-05$ & 0.000 & -1.065 & 0.315 \\
Global exports of all other products (MT) & $4.15 \mathrm{E}-09$ & 0.000 & 1.233 & 0.249 \\
\hline
\end{tabular}

$\mathrm{R}=0.842, \mathrm{R}^{2}=0.708$, Adjusted $\mathrm{R}$ square $=0.449, \mathrm{SE}=9.78155, \mathrm{~F}=2.71$

**, * meaning significant at 0.05 and 0.1 level

\subsection{Application of Porter's analysis of Competitiveness Determinants in the Sugar Industry in Swaziland}

In Table 3 the trends in the determinants of competitiveness of the sugar industry in Swaziland are indicated. In the study the determinants of competition were rated to have either constraints when scoring between (1-2.99), moderate when scoring $(3-3.99)$ or enhancing when scoring (4 - 5.99) impact on competitiveness of the sugar industry in Swaziland.

In Table 3 factor conditions as determinants of competitiveness of the sugar industry are 
illustrated. With an overall mean of 2.82, factor conditions as a whole had a negative impact on the competitiveness of the sugar industry since it falls within the mean range (1 2.99). Also demand conditions with an overall mean of 1.96 score less than 2.99 , as a whole had a negative impact on the competitiveness of the sugar industry. In addition Related and Supporting Industries had an overall mean of 2.93 scoring between $1-2.99$, meaning that as a whole they had a negative impact on the competitiveness of the sugar industry.

However, Firm Strategy, Structure and Rivalry Conditions had a positive impact. With an overall mean of 4.22, firm strategy conditions as a whole had a positive (4-5.99) impact on competitiveness of the sugar industry. With an overall mean of 2.73, government support conditions were found to be constraining (1-2.99) the competitive advantage of the Swaziland sugar industry. Finally, chance conditions with an overall mean of 2.03 implies that they had a negative impact on the competitiveness of the sugar industry since the score was below 2.99 .

Table 3. Overall performance on the determinants of competitiveness

\begin{tabular}{ll}
\hline Determinant & $\begin{array}{l}\text { Overall } \\
\text { mean }\end{array}$ \\
\hline Factor Conditions & 2.82 \\
Demand Conditions & 1.96 \\
Related and Supporting firms & 2.93 \\
Firm Strategy, Structure and Rivalry Conditions & 4.22 \\
Government conditions & 2.72 \\
Chance conditions & 2.03 \\
\hline
\end{tabular}

Source: Own Calculations from the survey data of 2015

$(1-2.99)=$ Constraints; $(3-3.99)=$ moderate; $(4-5.99)=$ enhancing

4.4 Analysis of the factors that enhance the competitiveness of the sugar industry in Swaziland

Table 4 shows fourteen factors out of sixty three factors investigated as the major factors that enhance $(4-5.99)$ the competitiveness of the Swaziland sugar industry. These factors have been ranked using their median values starting with factors found to have a major positive impact on the competitiveness of the sugar industry. From the 2015 executive survey, it was clear that the critical key success factors to the competitiveness of the sugar industry in Swaziland were the compensation of management, business approach to human resource, relationship and networking, telecommunication and internet service, availability of credit and availability of unskilled labour. All the above factors had a median value of 5 . In order to ensure that the sugar industry remains competitive in the market and is able to attract and retain employees it provide competitive remuneration. Making relationship and networking had a positive impact on the competitiveness of the sugar industry. Since the local market size is too small, regional and international trade agreements provide opportunities for market. The continued growth of the sugar industry exports is dependent on Swaziland participation in the preferential markets, the future of which cannot be guaranteed. 
Other factors with a median value of 4 which enhance the competitiveness of the sugar industry were the application of efficient technology, production of environmentally friendly product, production of high quality product, spending on research and development, high competition among local firms, competition intensity among the local firms, local supplies availability and consumer trends.

Table 4. Factors Enhancing Competitiveness of the Sugar Industry in Swaziland.

\begin{tabular}{llll}
\hline Factor Conditions & Mean & Median & Standard Deviation \\
\hline Compensation of management & 4.30 & 5 & 1.02 \\
Business approach to human resource & 4.50 & 5 & 0.63 \\
Relationship and networking & 4.70 & 5 & 0.55 \\
Telecommunication and internet & 4.30 & 5 & 1.17 \\
services & & & \\
Availability of credit & 4.40 & 5 & 1.03 \\
Unskilled labour availability & 4.40 & 5 & 1.07 \\
Production processes & 4.03 & 4 & 0.61 \\
Environmentally friendly product & 4.27 & 4 & 0.69 \\
High quality product & 4.30 & 4 & 0.80 \\
Spending on research and development & 4.00 & 4 & 0.72 \\
Local firm competition & 4.20 & 4 & 0.81 \\
Competition intensity & 4.10 & 4 & 0.52 \\
Local supplies availability & 4.00 & 4 & 0.69 \\
Consumers trends & 4.10 & 4 & 1.17 \\
Enhancements = (4 - 5.99) & & & \\
\hline
\end{tabular}

Source: Own Calculations from the survey data of 2015

$(1-2.99)=$ Constraints; $(3-3.99)=$ moderate $;(4-5.99)=$ enhancing

\subsection{Factors constraining the competitiveness of the Swaziland Sugar industry}

In Table 5 thirty one factors out of sixty three factors investigated were found as the major factors that constrains (1-2.99) the competitiveness of the Swaziland sugar industry. These factors have been ranked using their median values starting with factors found to be the major constraints. With median value of 1 , the local market size was found to have the most constraining effect on the competitiveness of the Swaziland sugar industry. This is not good for the sugar industry. This is because the role of the domestic market is to create the demand

for the product with stringent standards and drive specific performance characteristic that will be valued by international market. This will increase the value of products for domestic consumption and push local firm competitiveness not only towards more efficient production but also towards the desires and expectation of demanding international markets. The issue of small size of the market also slows down investment in new technology by the industries. Swaziland is a small country with just over a million people. Such a small population necessitates an outbound marketing strategy for its products. 


\section{I Macrothink}

Journal of Agricultural Studies

ISSN 2166-0379

2016, Vol. 4, No. 3

Other factors with a median value of 1 were also found to have a constraining effect on

the competitiveness of the sugar industry and these were: cost of financing business, cost of transport, cost of supplying inputs, public sector effectiveness on service delivery and exchange rates. The sugar cane growing sector remains vulnerable to increases in fertilisers, chemicals and haulage costs. Also as half of the sugar sales are destined for the EU and other markets outside the Common Monetary Area, the contracts entered into are denominated in foreign currency. Currencies used are either the Euro or US Dollar. Significant currency fluctuations of the South African Rand have a huge impact on revenues

With median value of 2, unskilled labour quality, cost, skilled labour cost, professional labour availability, professional labour cost, cost of infrastructure, cost of technology, availability of water, cost of water, local buyers sophistication, local buyers slow adoption of product, internalization, local consumers concern on ethics, concern on environmentally friendly product and local supplies sustainability were among other factors found to constraint the competitiveness of the sugar industry.

Table 5. Factors That Constraint the Competitiveness of the Sugar Industry in Swaziland

\begin{tabular}{|c|c|c|c|}
\hline Factor Conditions & Mean & Median & $\begin{array}{r}\text { Standard } \\
\text { Deviation }\end{array}$ \\
\hline Local market size & 1.10 & 1 & 0.30 \\
\hline Growth of local market & 1.30 & 1 & 0.79 \\
\hline Cost of financing business & 1.43 & 1 & 0.68 \\
\hline Cost of transport & 1.50 & 1 & 0.57 \\
\hline Cost of supply of inputs & 1.60 & 1 & 0.90 \\
\hline Availability of transport companies & 2.00 & 1 & 1.29 \\
\hline $\begin{array}{l}\text { Public sector personnel effectiveness on service } \\
\text { delivery }\end{array}$ & 1.60 & 1 & 0.77 \\
\hline Exchange Rates & 1.60 & 1 & 0.89 \\
\hline Unskilled labour quality & 2.00 & 2 & 0.69 \\
\hline Unskilled labour cost & 1.60 & 2 & 1.19 \\
\hline Skilled labour cost & 2.60 & 2 & 0.96 \\
\hline Professional labour availability & 1.93 & 2 & 1.05 \\
\hline Professional labour Cost & 2.10 & 2 & 1.32 \\
\hline Cost of infrastructure & 2.50 & 2 & 1.07 \\
\hline Cost of technology & 2.50 & 2 & 1.17 \\
\hline Availability of water & 2.10 & 2 & 0.62 \\
\hline Cost of water & 2.23 & 2 & 0.89 \\
\hline Local buyers sophistication & 1.90 & 2 & 0.55 \\
\hline Local buyers adoption of product & 1.60 & 2 & 0.62 \\
\hline - Internalization & 1.83 & 2 & 0.59 \\
\hline Local consumers concern on ethics & 1.83 & 2 & 0.64 \\
\hline Concern on environmentally friendly product & 2.00 & 2 & 0.52 \\
\hline Local supplies sustainability & 2.20 & 2 & 0.70 \\
\hline
\end{tabular}


Electricity supplies

Quality and trustworthy

Public sector personnel competence

Regulation on international trade

Prevalence of crime

HIV and AIDS

Global political development

Local political environment

$\begin{array}{lll}2.03 & 2 & 1.03 \\ 2.63 & 2 & 0.81 \\ 2.03 & 2 & 0.96 \\ 2.10 & 2 & 0.84 \\ 2.33 & 2 & 0.66 \\ 1.80 & 2 & 0.61 \\ 2.23 & 2 & 0.50 \\ 2.20 & 2 & 0.41\end{array}$

Source: Own Calculations from the survey data of 2015.

$(1-2.99)=$ Constraints; $(3-3.99)=$ moderate $;(4-5.99)=$ enhancing

\section{Conclusions and Recommendations}

\subsection{Conclusions}

The study found that the Swaziland sugar industry has a higher comparative advantage in the global market compared to the other countries. However, its comparative advantage heavily rely on preferential market access. Also global market price, exchange rate and the value of sugar exports were found to have a significant influence on the Relative Trade Advantage indices of the sugar industry internationally. Under the global sugar price the comparative advantage of the sugar industry in Swaziland was found to be decreasing. Based on these findings, the null hypothesis that economic conditions, production condition do not significantly affect the Relative Trade Advantage of Swaziland sugar industry, was rejected.

Based on Porter`s (1990) model results, the determinants of competitiveness which had a positive impact on the competitiveness of the sugar industry locally were compensation of management, business approach to human resource, relationship and networking, telecommunication and internet service, availability of credit and availability of unskilled labour. Other factors which enhances the competitiveness of the sugar industry local were the application of efficient technology, production of environmentally friendly product, production of high quality product spending on research and development, high competition among local firms, competition intensity among the local firms, local supplies availability and consumer trends.

Some factors were found to have a major constraining effect on the competitiveness of the Swaziland sugar industry. They included small local market size, slow growth of local market, cost of financing business, costs of transport, cost of supplies of inputs, public sector personnel effectiveness on service delivery and exchange rates.

\subsection{Recommendations for Action}

\section{a) Development of an Industry Policy Strategy}

Government in consultation with the industry representatives should consider development and implementation of an industry policy strategy for the sugar industry intended to ensure its survival while local and international market access improvements are being developed.

\section{b) Increase in Productivity and Efficiency}




\section{Macrothink}

Journal of Agricultural Studies

ISSN 2166-0379

2016, Vol. 4, No. 3

Efforts by the Swaziland sugar industry should be continuously exerted to improve operational efficiencies at both field and factory levels. This entails ongoing training and upgrading of labour skills, installation of better equipment and generally adopting new technologies as well as new techniques.

\section{c) Exploiting New Market Opportunities}

There is a need for the sugar industry to exploit new market opportunities. This can be through strengthening Regional trade agreements to increase market for our sugar.

d) Reduction in production costs, transport Costs and financing costs

There is still work to be done to get the unit cost of production down even lower.

Hauling of cane and transportation of sugar are two significant components of the cost of sugar which had a negative impact on the competitiveness of the industry. Therefore, sugarcane growers should respond to sugarcane transportation costs by delivering sugarcane to the nearby factory. Also government should consider investing in railway network which could provide transport at the lower costs for the producers.

\section{e) Diversification or Value Addition}

The industry need to invest on producing ethanol from sugarcane or from molasses. The Swaziland sugar industry should do whatever they can in order to increase their export not only in terms of sugar but in other products as well. Raw sugar is a primary commodity. If exported as is, there is a loss of potential domestic income and employment. This potential loss can be minimised via more value-added activities that use sugar as one of the major inputs.

\section{References}

Balassa, B. (1977). Revealed comparative revisited: Analysis of relative export shares of the industrial countries, 1953-1971. Manchester, 45, 327-344.

Balassa, B. (1989). Comparative advantage, trade policy and economic development (2nd edition). London, Harvester Wheat sheaf, New York.

Esterhuizein, D. (2006). An evaluation of the competitiveness of the South African agribusiness sector. University of Pretoria, Pretoria, South Africa.

Esterhuizen, D. (2010). Sugar Production in Swaziland. Global Agricultural Network. USDA, Mbabane, Swaziland.

Esterhuizein, D. (2014). An Assessment of Commodity and Trade Issues. USDA, Mbabane, Swaziland.

Gass, D. (2012). Challenges and Opportunities for the African Sugar Industry. SARPN, Pretoria, South Africa.

Harrison, N. G., and Kennedy, P. L. R. W. (1998). Analyzing Agribusiness competitiveness: The case of the United States Sugar Industry. JAI Press inc.

Matsebula, W. (2008). Biofuels As A Response to Energy and Competitiveness Needs For 


\section{Macrothink}

Journal of Agricultural Studies

ISSN 2166-0379

2016, Vol. 4, No. 3

The Swaziland Sugar Industry. Swaziland Sugar Association, Mbabane, Swaziland.

National Adaptation Strategy Report (2010). Ministry of Economic Planning and Develompent, Mbabane, Swaziland.

Nerslihan, A. (2012).Defining and Measuring Competitiveness: A Comparative Analysis of Turkey. International Journal of Basic and Applied Sciences, 12(2).

Porter, M. E. (1990). The Competitive advantage of nations. London, Macmillan. http://en.wikipedia.org/wiki/Porter_5forces_analysis. 5/10/2014.

Porter, M. E. (1998). The competitive Advantage of Nations. Macmillan Business Review, 33.

Swaziland Sugar Association (2010). Annual Report. Mbabane, Swaziland.

Swaziland Sugar Association (2012). Annual Report. Mbabane, Swaziland.

Swaziland Sugar Association (2013). Annual Report. Mbabane, Swaziland.

Tsengiwe, S. (2014). Increased in the Dollar base reference price of sugar. The International Trade Administration Commission of South Africa, Pretoria, South Africa.

Westlake, A. (2004). A Comprehensive Agricultural Sector Policy for Swaziland. Ministry of Agriculture and Cooperatives, Mbabane, Swaziland.

\section{Copyright Disclaimer}

Copyright for this article is retained by the author(s), with first publication rights granted to the journal.

This is an open-access article distributed under the terms and conditions of the Creative Commons Attribution license (http://creativecommons.org/licenses/by/3.0/). 